Jana S. Rošker

\title{
Huang Chun-chieh 黃俊傑 (ur.): Dongya ruxue yanjiude huigu yu fazhan 東亞儒學研究的回顧與 展望 (Retrospektiva in perspektive raziskovanja vzhodnoazijskega konfucianizma)
}

\section{Tajpej: Taida chuban she, 2006, 320 strani}

Pričujoča knjiga je bila objavljena kot del raziskovalnega programa vzhodnoazijskih konfucianizmov v okviru Inštituta naprednih študij v humanistiki in družboslovju, ki je bil leta 2006 vzpostavljen na Nacionalni tajvanski univerzi. Raziskovalni program se je usmeril v preučevanje vzhodnoazijskega konfucianizma, njegov rezultat pa je bilo med drugim sedem obsežnih knjižnih serij.

Knjigo Retrospektiva in perspektive raziskovanja vzhodnoazijskega konfucianizma je uredil in objavil Chun-chieh Huang, eden najprepoznavnejših sodobnih tajvanskih strokovnjakov za konfucianizem. Urednik, ki je hkrati avtor več prispevkov, je profesor zgodovine, raziskovalni sodelavec na Inštitutu za kitajsko literaturo in filozofijo na Academii Sinici v Tajpeju, častni predsednik Kitajskega združenja za splošno izobraževanje in dekan Inštituta za podiplomske študije v humanizmu in družboslovju na Nacionalni tajvanski univerzi v Tajpeju. Kot direktor Programa vzhodnoazijskih konfucianizmov na tej univerzi je uredil več knjig o tem tradicionalnem miselnem toku. Te zaobjemajo obširno knjižno zbirko na temo vzhodnoazijskih civilizacij (東 亞文明研究囁書), ki je nastala kot posledica dejstva, da na globalni ravni ta regija postaja vse pomembnejša.

$\mathrm{V}$ 21. stoletju so vzhodnoazijske družbe namreč na novo začrtale zemljevid napredka: ravnovesje ekonomske - in vse bolj tudi politične - moči se $z$ evroameriških območij nagiba $\mathrm{k}$ vzhodnoazijskim. Ta preobrat nas sooča s številnimi novimi vprašanji, vezanimi na preobrazbo materialnih in intelektualnih paradigem, ki ne določajo le razvoja vzhodnoazijskih družb kot takih, temveč izrazito vplivajo tudi na mednarodne odnose. Strateške rešitve teh vprašanj morajo upoštevati širše vidike znotraj konteksta posameznih kulturnih ozadij. Ti niso omejeni na ekonomska in ekološka vprašanja, temveč vključujejo tudi politične ter družbene vloge ideologij in kulturno pogojenih vrednot, ki predstavljajo osrednje epistemološke temelje, na katerih slonijo najbolj značilne in trajne institucije teh družb. Serija se torej ukvarja s številnimi ključnimi vidiki, ki opredeljujejo te idejne temelje, vključno z več izdajami, 
posvečenimi raziskovanju konfucijanskih teorij in praks. Pričujoča knjiga predstavlja enega najbolj izčrpnih delov te knjižne serije in je nepogrešljiv vir dragocenih informacij za vsakega teoretika, ki se ukvarja z vzhodnoazijskim konfucianizmom.

Govoriti o Vzhodni Aziji kot konceptu pa je lahko tvegano. Zato prof. Huang Chun-chieh ta pojem razjasni že v predgovoru. Poudari, da je njegova razlaga pomembna, saj se v akademskih krogih teh regij še vedno pojavlja veliko predsodkov in »nepotrebnih nesporazumov«, ko gre za idejo Vzhodne Azije. Koncept je bil sicer pogosto razumljen kot implikacija na določeno zgodovinsko konotacijo, vezano na japonske imperialne težnje na dotičnem geografskem območju. Prof. Huang poudarja, da v pričujoči antologiji termin Vzhodna Azija nikakor ni uporabljen na tak univerzalističen in/ali esencialističen način. Namesto tega je razumljen kot termin, ki implicira multikulturne dimenzije in izvira iz proste interakcije med raznolikimi vzhodnoazijskimi kulturami na eni ter sodobnimi zgodovinskimi interakcijami med njimi in kulturami našega skupnega sveta na drugi strani.

Zatorej ideja Vzhodne Azije, kot je uporabljena v pričujoči antologiji, ne sledi striktni ločnici med »centrom « in "periferijo«, kot lahko zasledimo pri Wallersteinovi teoriji svetovnega sistema in v podobnih zgodnejših diskurzih znotraj postkolonialnih študij. V dveh tisočletjih zgodovine, ki kleše teoretske raziskave, ki tvorijo obravnavano knjigo, tovrstne ločnice niso bile nikoli dovolj statične, da bi se lahko izoblikovale te kategorije; bile so dinamični del vzajemnega vpliva kultur in zgodovin ter so v svojih lastnih tokovih prestale številne korenite spremembe.

Po mojem mnenju je enostavno razumeti, zakaj je knjiga, predstavljena $\mathrm{v}$ tej recenziji, tako pomembna, še posebej če upoštevamo dejstvo, da je konfucianizem skozi stoletja v večini vzhodnoazijskih regij predstavljal osrednji temelj kultur in da še vedno tvori mnogo elementov njihovih vrednostnih sistemov. Tu lahko omenimo še eno skupno kulturno podlago, ki je v dolgih stoletjih povezala območje, namreč piktografsko pisavo.

Glavni cilj pričujoče antologije je tako dvojen: skozi prizmo raziskovanja skupne konfucijanske podlage si prizadeva predstaviti primerjave in vzajemen vpliv glavnih vzhodnoazijskih držav, predvsem Kitajske, Japonske in Koreje, ter znotraj tega raziskovalnega področja ovrednotiti interakcije med temi državami in Zahodnim svetom.

Antologija sestoji iz devetih obširnih študij, ki se ukvarjajo $z$ različnimi vidiki vzhodnoazijskega raziskovanja znotraj konfucianizma. Začne se s študijo, ki jo je napisal Huang Chun-chieh, urednik antologije, in vsebuje izčrpno splošno predstavitev obstoječega stanja pri interpretiranju konfucijanskih klasikov v Vzhodni Aziji in obete 
za njegovo prihodnost. Uvodna predstavitev in kritična ocena obstoječega stanja na raziskovalnih področjih oblikujeta podlago, ki avtorju po eni strani omogoča, da oriše najverjetnejše prihodnje usmeritve in smernice pri raziskovanju konfucijanskih klasikov, po drugi strani pa, da oblikuje najrelevantnejša raziskovalna vprašanja, ki so še vedno odprta za raziskave znotraj področja, ki ima, kot kaže študija, velik potencial za nadaljnji razvoj. Kot izpostavi avtor, študija ne predstavlja celovitosti vseh del, ki so bila v Vzhodni Aziji napisana znotraj tega raziskovalnega področja, temveč vsebuje zgolj teoretično evalvacijo omenjenih diskurzov. Osredotočena je na probleme, vezane na njihov obseg in vsebine, ter na kulturna in socialna ozadja, predvsem $\mathrm{z}$ namenom opozoriti na ta vprašanja.

Druga študija, ki jo je napisal japonski učenjak Masayuki Sato, je sestavljena iz šestih kronološko strukturiranih sekcij. Te predstavljajo japonske raziskave Xunzija v 20. stoletju. Ta pregled ne predstavlja kritične evalvacije materiala, temveč je bolj kot to cilj predstavitev osrednjih japonskih smernic, del in avtorjev, ki delajo znotraj tega raziskovalnega področja, kitajskemu akademskemu bralstvu. Tej sekciji sledi poglavje o ritualnih knjigah iz dinastij Tang in Song skozi prizmo kontroverzne teze, po kateri naj bi obdobje konca dinastije Tang in začetka dinastije Song predstavljalo mejo med antično Kitajsko in kitajskim srednjim vekom. Chang Wen-Chang, avtor teh šestih poglavij, je svoje izsledke utemeljeval $\mathrm{z}$ rezultati starejše raziskave, ki so jo izpeljali japonski učenjaki. Izdelali so obširne raziskave reform in družbenih transformacij, ki so potekale v zgoraj omenjenih dinastijah. Opravljene so bile razmeroma natančne analize njihovih ritualnih knjig, ki so vsebovale glavne kriterije in osrednje kode formalnih družbenih interakcij, da bi tako lahko dodatno osvetlili zgoraj omenjeno dilemo.

$\mathrm{V}$ naslednjem poglavju je Lee Bong Kyoo predstavil nekaj osrednjih točk in glavnih vprašanj $\mathrm{v}$ zvezi s korejskimi raziskavami na področju konfucianizma. To poglavje se osredotoča predvsem na korejsko raziskovanje in elaboracijo Jeong Yakyongovih (širše znanega pod imenom Dasan) naukov, ki so bili kasneje še podrobneje obdelani v Huang Chun-chiehjevi knjigi Vzhodnoazijski pogled na Dasanov diskurz in korejski konfucianizem (東亞視域中的茶山學與朝鮮儒學). Ta je bila objavljena leta 2006 v okviru iste serije kot pričujoča antologija. Poglavje, razdeljeno na sedem sekcij, ponuja izčrpno predstavitev korejskega raziskovalnega materiala. Ta se nanaša na tega pomembnega učenjaka, ki je spisal izjemno vplivne knjige o filozofiji, znanosti in teorijah vladanja, zasedal pomembne administrativne pozicije in bil znan tudi kot poet. Njegova filozofska pozicija se pogosto identificira z neokonfucijansko šolo praktičnega učenja 實學 (korejsko Silhak), predvsem če se osredotočimo na raziskovanje njegove filozofije, njegove interpretacije konfucijanskih klasikov in ritualnosti ter na njegove teorije države. 
Naslednje poglavje, ki ga je napisal Huang Yueh Lan, je posvečeno raziskovanju in kritični evalvaciji japonskega konfucianizma. V šestih sekcijah analizira povojne japonske interpretacije Masao Maruyamovih klasičnih del in raziskave japonske politične misli ter vzpostavi temeljno kritiko Maruyamovih teorij. Te teorije so izhajale iz iskanja specifičnih izvorov japonskega razsvetljenstva in modernosti skozi analizo Dong Zhongshujevega reformiranega konfucianizma, znanega pod imenom Dezhoujev konfucianizem. S pomočjo te kritike in obrazložitve nekaterih napak v interpretaciji poskuša avtor zastaviti bodoča vodila za nadaljnje možne smernice pri preučevanju Dezhoujevega konfucianizma. Tem esejem sledi še eno poglavje, ki poudarek prav tako namenja konfucijanskim raziskavam na Japonskem. Napisal ga je Kun-Chiang Chang, posveča pa se predvsem japonskim raziskavam naukov in diskurzivnega razvoja del Wang Yangminga, najpomembnejšega predstavnika šole srčne zavesti (Xin xue 心學). Poglavje, ki je razdeljeno na osem različnih sekcij, izpostavi pomembnost japonskega raziskovalnega področja zaradi njegovega prispevka pri širjenju in internacionalizaciji vpliva tega pomembnega filozofa. Zaradi pričujočega japonskega raziskovalnega dela Wang Yangmingova filozofija in njene teoretične implikacije niso bile zgolj nadgrajene, temveč tudi postavljene $\mathrm{v}$ širši vzhodnoazijski kontekst. V tem smislu so te raziskave dober primer plodnega sodelovanja in interakcije med posameznimi kulturami, ki so bile (in še vedno so) pod vplivom konfucijanske filozofije.

Shyu Shing-Ching je avtor sedmega poglavja, ki se ukvarja s kitajskim in japonskim raziskovanjem del Zhu Shunshuija (Shu Shunsui, 1600-1682), kitajskega učenjaka iz časa dinastije Ming, ki je živel in delal na Japonskem ter tako močno pripomogel k izmenjavi med Kitajsko in Japonsko, hkrati pa tudi k japonski izobrazbi in intelektualni zgodovini.

Naslednje poglavje, ki ga je napisal urednik pričujoče antologije, prof. ChunChieh Huang, je pomemben ekskurz od glavne smeri pisanja, katere primarni fokus predstavlja vzhodnoazijsko raziskovanje konfucianizma. Ukvarja se predvsem s povojnimi raziskavami, ki so jih v obdobju 1950-1980 izvajali sinologi iz ZDA. Ta ekskurz je pomemben, saj širi obzorje osrednje konceptualizacije pričujoče knjige; temelji namreč na odkrivanju medkulturnih dimenzij raziskovanja konfucijanstva. Avtor opozarja, da v nasprotju $\mathrm{z}$ evropsko sinologijo, ki sega $\mathrm{v}$ 13. stoletje in je bila - še posebej na področju konfucijanskih študij - zelo dobro dokumentirana, severnoameriško raziskovanje na tem področju doslej ni bilo dovolj celovito obravnavano. Zato se je odločil naročiti in širši kitajski akademski javnosti predstaviti obsežen izbor najpomembnejših tovrstnih raziskovalnih del, ki so jih izvedli ameriški sinologi, v prvi vrsti zato, ker so se po drugi svetovni vojni vodilne smernice kitajskih in konfucijanskih študij, tako glede metodologije kot tudi glede vsebine, iz evropskih regij postopoma premaknile v severnoameriške. Predhodna raziskovanja, ki so se 
prej močno zanašala na filološke raziskave, so tako nadomestile aktualnejše metode, ki se osredotočajo na elaboracijo določenih tematik znotraj konfucijanskih raziskav ter na njihove družbene, politične in zgodovinske kontekste. Chun-Chieh Huang poudarja, da so na začetku zgodnjih 70 . let prejšnjega stoletja tudi ameriški sinologi pričeli uporabljati nekatere modernizirane raziskovalne metode, vezane na besedila, vključujoč analize konceptualnih in vrednostnih vidikov konfucijanskih naukov. Avtor zaključi, da sta obe metodi, ki ju še vedno uporabljajo tuji učenjaki, komplementarni in lahko veliko prispevata $\mathrm{k}$ nadaljnjemu razvoju konfucijanskega raziskovanja, ne zgolj v Vzhodni Aziji, temveč tudi v širšem globalnem kontekstu.

Zadnje, osmo poglavje antologije je napisal Chao-yang Pan, predstavi pa specifične značilnosti povojnih konfucijanskih raziskav na Tajvanu, pri čemer se osredotoča tako na njihove jedrne probleme kot tudi na njihov širši pomen. Avtor izpostavi, da tajvanskega raziskovanja znotraj tradicionalne kitajske filozofije ne moremo ločiti od njegovega družbenega in političnega konteksta, vključno z njegovo kolonialno preteklostjo in pozahodeno sedanjostjo. Poglavje tako izpostavlja, da je rekonstrukcija jedra tradicionalnih vrednot, ki prevladujejo v klasični kitajski filozofiji, ter njihova inkorporacija v moderno tajvansko družbo glavna naloga, ki bi morala v prihodnje voditi tajvansko raziskovanje konfucianizma.

Dodamo lahko, da bi moderno raziskovanje konfucianizma lahko na ta način pomembno prispevalo $\mathrm{k}$ vnovični vzpostavitvi lokalnih kulturnih identitet in tako oblikovalo nove, modernizirane podobe ne samo tajvanske, temveč tudi kitajske in vzhodnoazijske kulturne dediščine. Knjiga, predstavljena v tem pregledu, je pomemben korak $\mathrm{k}$ tovrstni akademski analizi. 